Sympozjum

Rok XXIII 2019, nr 1(36), s. 31-60

\author{
ks. Zygfryd Glaeser \\ Uniwersytet Opolski, Wydział Teologiczny \\ ORCID: 0000-0002-8791-0175; e-mail: Zygfryd.Glaeser@uni.opole.pl \\ https://doi.org/10.4467/25443283SYM.19.003.10632
}

\title{
TEOLOGIA MIĘDZY SŁOWEM I MILCZENIEM
}

\section{THEOLOGY BETWEEN WORD AND SILENCE}

\begin{abstract}
Abstrakt
Człowiek jako istota rozumna i wolna, ze swej natury może i powinien docierać do prawdy, trwać przez niej i całe swoje życie opierać na prawdzie. Prawda jest „miejscem spotkania” rozumu i wiary, które tworzą między sobą głęboką i nierozerwalną jedność, uznając jednocześnie swoją autonomiczność w dochodzeniu do prawdy. Bogata historia dorobku ludzkiego intelektu świadczy o tym, że „człowiek w ciągu stuleci przebył pewną drogę, która prowadziła go stopniowo do spotkania z prawdą i do zmierzenia się z nią" (FR 1). Dzięki swej osobowej naturze, człowiek szuka prawdy ponadempirycznej, mającej wymiar egzystencjalny, związany z kontekstem jego życia. Właśnie w kontekście prawdy rozum i wiara nie pozostają wobec siebie w opozycji, lecz tworzą między sobą głęboką i nierozerwalną jedność (por. FR 16). Choć rozum i wiara tworzą jedność, to w istocie stanowią dwie różne drogi dochodzenia do prawdy, a zarazem dwa różne sposoby przeżywania relacji wobec niej.

Podstawowym zadaniem teologii jest rozumna służba prawdzie odkrywanej $\mathrm{w}$ wierze. Do jej instrumentarium należą, na równi, wiara i rozum. W istocie
\end{abstract}


rzeczy, w teologii chodzi o próbę zrozumienia relacji łączącej człowieka z żywym Bogiem i opowiedzenia o niej. Teologia ma charakter dialogiczny. Specyficzne jest dla niej to, że w dialogu tym uczestniczy sam Bóg. Każda prawda domaga się jej wyrażenia, uzewnętrznienia. Wypowiedzi o Bogu i o relacji człowieka z Bogiem mogą mieć różny charakter i mogą przybierać różne kształty. Ostatecznie chodzi jednak o próbę wypowiedzenia tego, co ze swej istoty jest niewypowiadalne, a jednak w jakiejś formie powinno zostać wypowiedziane. Najistotniejszym nośnikiem i znakiem prawdy teologalnej jest słowo. Ale i ono ma różną ekspresję i może być wyrażane na wiele sposobów. Każda wypowiedź o Bogu jest fragmentaryczna, cząstkowa. Zawiera w sobie element paradoksalności wynikającej z faktu niemożności jej wyrażenia w sposób całkowicie jednoznaczny i całościowy. Boga nie można „zamknąć” ani „zmieścić”, ani też w pełni wypowiedzieć, stosując teologiczne formuły. Każda z nich naznaczona jest cząstkowością. Dla ludzkiego umysłu Bóg pozostaje zawsze tajemnicą. Chrześcijański Wschód dystansuje się od wypowiadania i interpretowania prawd chrześcijańskiej wiary w formie teologicznych traktatów. Abstrahuje także od tworzenia wielkich teologicznych systemów pojęciowych. Przejmując bizantyjskie wzorce myślenia, ukształtował typ duchowości o ukierunkowaniu mistycznym, liturgicznym i ikonograficznym. Na pierwszy plan wysuwa kontemplację Tajemnicy, a nie czysto racjonalne podejście do niej. Wychodzi z założenia, że kontemplacja Tajemnicy, otwarcie się na Jej oświecenie prowadzi do Jej poznawania, bez konieczności jej definiowania. Tak więc słowo i milczenie jawią się jako równoważne wymiary teologicznej komunikacji. Następują po sobie i się dopełniają. Mają wspólny cel: doprowadzenie do autentycznego dialogu i do pogłębienia bliskości człowieka z Bogiem i ludzi między sobą.

Słowa kluczowe: teologia, Bóg, Chrystus, Duch Święty, słowo, milczenie, kontemplacja, hezychazm, apofatyzm 


\section{Abstract}

Man, as a rational and free being, by his nature, can and should reach the truth, abide through it and all his life based on truth. Truth is a "meeting place" of reason and faith that create a deep and inseparable unity, recognizing at the same time its autonomy in reaching the truth. The rich history of the achievements of the human intellect testifies to the fact that "man has travelled a certain path over the centuries, which led him gradually to meet with the truth and to face it" (FR 1). Due to his nature, man seeks a non-empirical truth with an existential dimension related to the context of his life. It is in the context of truth that reason, and faith do not remain in opposition to each other but create a deep and inseparable unity between them (see FR 16). Although reason and faith form unity, they are, in fact, two different ways of reaching the truth, and at the same time, two different ways of experiencing such relationship.

The essential task of theology is the rational service of truth discovered in faith. Its instruments include equally faith and reason. Theology is about trying to understand the relationship between man and the living God and telling about it.

Every truth demands its expression, externalization. Statements about God and the relationship between man and God can be different and can take various shapes. Ultimately, however, it is about trying to say what is inherently unspeakable, but in some form, it should be spoken. The most important medium and the sign of theological truth is the word. But it also has different expressions and can be expressed in many ways. Every statement about God is incomplete and partial. It contains an element of paradoxicality resulting from the fact that it cannot be shown in a wholly unambiguous and comprehensive way. God cannot be "shut down", or "not fit to someone" nor fully express using theological formulas. Each of them is marked by partiality. God is always a mystery to the human mind. The Christian East distances itself from speaking out and interpreting the truths of Christian faith in the form of theological treaties. It also disregards the creation of high religious conceptual systems. Taking over the Byzantine models of thinking, He shaped a type of spirituality with a mystical, liturgical, and iconographic orientation. The contemplation of the mystery 
is the foreground, not the purely rational approach to it. It assumes that the reflection of the Mystery, the openness to the enlightenment leads to learning without the need to define it.

Thus word and silence appear as similar dimensions of theological communication. They follow each other and are completed. They have a common goal: bringing about a genuine dialogue and deepening the closeness of man with God and people with each other.

Keywords: theology, God, Christ, Holy Spirit, word, silence, contemplation, hesychism, apophaticism

„Wiara i rozum (fides et ratio) są jak dwa skrzydła, na których duch ludzki unosi się ku kontemplacji prawdy. Sam Bóg zaszczepił w ludzkim sercu pragnienie poznania prawdy, którego ostatecznym celem jest poznanie Jego samego, aby człowiek - poznając Go i miłując - mógł dotrzeć także do pełnej prawdy o sobie (por. Wj 33,18; Ps 27[26],8-9; 63[62],2-3; J 14,8; 1 J 3,2)"1 - tymi słowami św. Jan Paweł II rozpoczął swoją encyklikę Fides et ratio. Zamierzał on natchnąć ludzkiego ducha do odważnej konfrontacji z prawdą i zachęcić rozum do podjęcia poszukiwania prawdy, jako niezbywalnej i konstytutywnej potrzeby bytu, jakim jest człowiek. Jako istota rozumna i wolna, ze swej natury może i powinien docierać do prawdy, trwać przy niej i całe swoje życie opierać na prawdzie. Prawda jest „miejscem spotkania” rozumu i wiary, które tworzą między sobą głęboką i nierozerwalną jedność, uznając jednocześnie swoją autonomiczność w dochodzeniu do prawdy². Jan Paweł II wskazuje na fakt, że wzajemna relacja rozumu i wiary oraz ich specyficzna natura, winny być analizowane w świetle podstawowej dążności osoby ludzkiej, jaką jest skierowanie ku prawdzie.

1 Jan PaweŁ II, Encyklika Fides et ratio, Rzym 1998 (dalej: FR), Wprowadzenie.

2 Zob. P. OснотnY, Fides et ratio. Dwa porządki poznania prawdy, „Warszawskie Studia Pastoralne UKSW” 3(32) (2016), s. 102. 


\section{Teologia jako służba prawdzie}

Bogata historia dorobku ludzkiego intelektu świadczy o tym, że „człowiek w ciągu stuleci przebył pewną drogę, która prowadziła go stopniowo do spotkania z prawdą i do zmierzenia się z nią"3 czytamy w encyklice Fides et ratio. Jan Paweł II konsekwentnie zwraca się ku człowiekowi, stawiającemu pytania o otaczający go świat, a także o sens własnej egzystencji. Zwraca uwagę na fakt, że rozum ludzki, poznając na drodze empirii tajemnice wszechświata, odkrywa w nim obecność wszechmocnego i mądrego Stwórcy jako Przyczyny sprawczej wszystkiego, co istnieje ${ }^{4}$. Odczytuje także swoje powołanie, którym jest „dążenie do prawdy, prze-

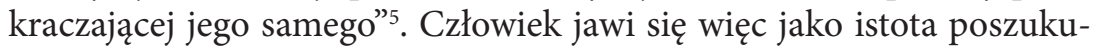
jąca prawdy, gdyż ludzki rozum z niepohamowaną mocą, jako istotny element życiowego dynamizmu, jest ze swej natury skierowany ku praw$\mathrm{dzie}^{6}$. Zdolność do refleksji nad światem i nad samym sobą jest podstawą ludzkiej podmiotowości. Poznając prawdę, człowiek „urzeczywistnia samego siebie"'. Dzięki swej osobowej naturze, szuka prawdy ponadempirycznej, mającej wymiar egzystencjalny, związany z kontekstem jego życia. Prawda obiektywna o rzeczywistości jest zarazem prawdą uniwersalną ${ }^{8}$. „Prawda bowiem nie przyjmuje żadnych granic. Jest dla wszystkich i dla każdego. A gdy prawdę tę czyni się w miłości (por. Ef 4,15), wówczas jeszcze bardziej staje się ona uniwersalistyczna"9. Uniwersalizm prawdy obiektywnej wymaga stosowania wielu metod badawczych, a także dialogu multilateralnego wielu różnych dyscyplin (przyrodniczych, filozo-

3 FR 1.

4 Zob. Jan PaweŁ II, Prawda i wolność. Do środowiska akademickiego (Rzym, 26.03.1981 r.), w: Jan Paweł II, Nauczanie społeczne, t. 4, Warszawa 1984, s. 74-75; P. OснотNy, Fides et ratio, dz. cyt., s. 103.

5 Zob. FR 5; 28.

6 Por. P. Ochotny, Fides et ratio, dz. cyt., s. 103; V. Possenti, Filozofia $i$ wiara, Kraków 2004, s. 18.

7 P. Оснотny, Fides et ratio, dz. cyt., s. 103. Zob. także. S. Kowalczyк, Prawda jako wartość w nauczaniu Jana Pawła II, „Ateneum Kapłańskie” 1(129) (530) (1997), s. 56.

8 Por. Jan Pawę II, Przemówienie Ojca Świętego do przedstawicieli świata nauki (Lublin 09.06.1987 r.), http://www.nauczaniejp2.pl/dokumenty/wyswietl/id/677 (odczyt z dn. 12.03.2019 r.).

9 Tenże, Przekroczyć próg nadziei, Lublin 1994, s. 126. 
ficznych i teologicznych) ${ }^{10}$. Określenie osoby ludzkiej jako istoty poszukującej prawdy wytycza perspektywę, w której dopiero możliwe staje się przedstawienie relacji rozumu i wiary i nakreślenie stopnia ich wzajemnego uzupełniania się.

Jan Paweł II akcentuje komplementarność prawdy naturalnej oraz prawdy objawionej. Właśnie w kontekście prawdy rozum i wiara nie pozostają wobec siebie w opozycji, lecz tworzą między sobą głęboką i nierozerwalną jednośćc ${ }^{11}$. Tych dwóch sposobów poznania nie można jednak ze sobą utożsamiać, podobnie jak nie można wykluczać jednego przez drugi. Mamy bowiem tu do czynienia $\mathrm{z}$ dwoma porządkami: przyrodzonym objawionym przez Boga Stworzyciela w powszechnym prawie naturalnym i nadprzyrodzonym - kiedy to Bóg komunikuje człowiekowi przez swoje Słowo prawdy niedostępne naturalnym władzom umysłu ludzkiego $^{12}$. Należy więc zauważyć, że choć rozum i wiara tworzą jedność, to $\mathrm{w}$ istocie stanowią dwie różne drogi dochodzenia do prawdy, a zarazem dwa różne sposoby przeżywania relacji wobec niej ${ }^{13}$.

Powiązanie rozumu i wiary jest możliwe jedynie na gruncie prawdy. „Jedność prawdy, naturalnej i objawionej, jest - jak to podkreśla św. Jan Paweł II - podstawowym postulatem ludzkiego rozumu, wyrażonym już w zasadzie niesprzeczności. Objawienie daje pewność tej jedności, pokazując, że Bóg Stwórca jest także Bogiem historii zbawienia" ${ }^{14}$. Nauki przyrodnicze, a nawet filozofia, nie są zdolne zaspokoić ludzkiego głodu prawdy poprzez udzielenie wyczerpujących odpowiedzi na wszystkie pytania człowieka. Ewangelia jest dopełnieniem prawdy naukowo-empirycznej i prawdy filozoficznej. Jednoznaczne są tu słowa Jezusa: "Ja się na to narodziłem i na to przyszedłem na świat, aby dać świadectwo prawdzie” $(J 18,37)^{15}$. „Ta właśnie jedność prawdy naturalnej i objawionej

${ }^{10}$ Zob. TENŻE, Kościól jest solidarny $z$ uniwersytetem. Do środowiska naukowego w Bolonii (Bolonia, 18.04.1982 r.), w: Jan Paweł II, Nauczanie społeczne, t. 5, cz. 1, Warszawa 1986, s. 93-100.

${ }^{11}$ Zob. FR 16.

${ }_{12}$ Por. P. ОснотnY, Fides et ratio, dz. cyt., s. 106.

${ }_{13}$ Por. tamże.

${ }^{14}$ FR 34 .

${ }^{15}$ Zob. FR 12. 
znajduje żywe i osobowe wcielenie w Chrystusie"16. Natura ludzka Syna Bożego sprawia, że prawda, choć absolutna, przestaje być daleka i abstrakcyjna ${ }^{17}$. W Chrystusie Objawienie przestaje być dla rozumu czymś zewnętrznym. Staje się bodźcem, który inspiruje rozum. Wiara otwiera przed rozumem nowe horyzonty, ukazując zagadnienia, których rozum bez Objawienia najprawdopodobniej nigdy by nie odkrył ${ }^{18}$.

Benedykt XVI podkreśla, że wiara i rozum, nie mogą być od siebie oddzielane ani też sobie przeciwstawiane, lecz powinny zawsze iść razem, powinny być traktowane integralnie ${ }^{19}$. „Wiara i rozum, jak napisał Augustyn po swoim nawróceniu, są «dwoma siłami, które prowadzą do poznania» (Contra Academicos, III, 20, 43)"20. Wierzący pragnie lepszego poznania Tego, w którym złożył swoją wiarę, i lepszego zrozumienia tego, co On objawił. Głębsze poznanie będzie domagać się z kolei większej wiary, coraz bardziej przenikniętej miłością: „wierzę, aby rozumieć, i rozumiem, aby głębiej wierzyć” 21 . Harmonia między wiarą a rozumem oznacza przede wszystkim to, że Bóg nie jest daleki: nie jest daleko od naszego rozumu i od naszego życia. Jest blisko każdego człowieka, blisko naszego serca oraz blisko naszego rozumu. Obecność Boga w człowieku jest bardzo głęboka i równocześnie tajemnicza, można ją jednak rozpoznać i odkrywać ${ }^{2}$. Podstawowym zadaniem teologii jest więc rozumna służba prawdzie odkrywanej w wierze. Do jej instrumentarium należą, na równi, wiara i rozum. W istocie rzeczy, teologii chodzi o próbę zrozumienia relacji łączącej człowieka z żywym Bogiem i opowiedzenia o niej.

${ }^{16}$ FR 34.

17 Zob. T. Dola, Historyczny kształt prawdy, w: S. Rabiej (red.), Prawda wobec rozumu i wiary, Opole 1999, s. 104.

18 Zob. P. Oснотny, Fides et ratio, dz. cyt., s. 109; E. Sienkiewicz, Zagadnienie prawdy w filozofii, „Poznańskie Studia Teologiczne” 20 (2006), s. 323.

19 Zob. Benedy Kт XVI, Dawajcie świadectwo o Bogu w świecie współczesnym. Rozmowa z młodzieżą Rzymu i Lacjum na placu św. Piotra, OsRomPol 6-7 (2006), s. 51.

20 Tenże, Wiara i rozum w nauczaniu św. Augustyna (audiencja generalna, 30.01.2008 r.), https://www.niedziela.pl/artykul/84572/nd/ (odczyt z dn. 15.02.2019 r.).

${ }^{21}$ Katechizm Kościoła katolickiego, Poznań 1994 (dalej: KKK), 158.

22 Zob. A. Proniewski, Problematyka wiary w nauczaniu Benedykta XVI, „Rocznik Teologii Katolickiej” 10 (2011), s. 122. 


\section{Dialogiczny charakter teologii}

Teologia jest swego rodzaju ludzką rozmową o Bogu. Ma charakter dialogiczny. Specyficzne jest to, że w dialogu tym uczestniczy sam Bóg ${ }^{23}$. Teologia oznacza i przekazywanie swego rozumienia wiary, i słuchanie, jak tę wiarę rozumieją inni. Jest także dzieleniem się, na różne sposoby, własnym doświadczeniem Boga. Teologia wskazuje na żywą obecność Boga zarówno w dyskursie teologicznym, jak i we własnym przeżywaniu doświadczenia z Nim. Bóg bierze czynny udział w procesie dochodzenia człowieka do pełni prawdy. Tak więc teologią jest również to wszystko, co jest racjonalną rozmową o spotkaniu z Bogiem prowadzoną w wierze.

Chrześcijaństwo w swoich najgłębszych pokładach jest religią dialogu. W dialog, który stanowi symbiozę elementu boskiego i ludzkiego, zaangażowany jest sam Bóg. Papież Paweł VI w encyklice Ecclesiam suam dzieje zbawienia określa mianem wielkiego dialogu, jaki Bóg prowadzi z człowiekiem. Jest to dialog miłości i partnerskiego zaufania. Wezwani są do niego wszyscy ludzie: „dzieje ludzkiego zbawienia przekazują (...) długi i różnorodny dialog, który Bóg w dalszym ciągu prowadzi z ludźmi (...). Bóg objawia coś z siebie samego, z tajemnic swojego życia jedynego w naturze i troistego. Jednocześnie zaś Bóg z jednej strony wskazuje, że chce być przez nas poznany jako miłość, a z drugiej strony, że pragnie, abyśmy Mu oddawali cześć i służyli - oczywiście przez miłość, nie nakazując nam nic ponadto. Do takiego dialogu, który częstokroć staje się zażyły i pełen ufności, jest powołane zarówno dziecko, jak człowiek wprowadzony w tajniki życia mistycznego, człowiek, którego dusza jest wypełniona rozmową z Bogiem"24. Dzięki niemu chrześcijanie uczą się „,razem”, jako siostry i bracia w wierze, wzrastać w misterium Chrystusa i Jego Kościoła. Dialog stwarza również możliwość poznawania siebie nawzajem oraz wspólnego wnikania w głębię prawd chrześcijańskiego Objawienia. Nie chodzi tu jednak tylko o czysto teoretyczne poznanie, ale o takie, które wciąga życiowo w obręb poznawanej rzeczywistości, otwiera

\footnotetext{
23 Zob. T. WęCŁAwski, Sieć. Wyprawa pierwsza. Pytanie o Jezusa, Kraków 1997, s. 27.

24 PaweŁ VI, Encyklika Ecclesiam suam, Rzym 1964, 70.
} 
nowe perspektywy, uwrażliwia na określony sposób postępowania i kształtowania życia. Staje się więc szansą spotkania w wierze, odnajdywania, budowania więzów eklezjalnych, a w konsekwencji wspólnego dawania świadectwa Ewangelii ${ }^{25}$.

„Postawa «dialogiczna» odpowiada naturze osoby i jej godności”26. Określa też płaszczyznę „uprawnionej różnorodności” w wyrażaniu tej samej wiary. Stanowi istotny element „na jedynej drodze do samospełnienia człowieka: zarówno poszczególnych osób, jak też każdej wspólnoty. Chociaż w pojęciu «dialog» zdaje się wysuwać moment poznawczy (dia-logos), każdy dialog ma również wymiar całościowy, egzystencjalny. Angażuje cały ludzki podmiot; dialog między wspólnotami angażuje w sposób szczególny podmiotowość każdej z nich. Nie jest tylko wymianą myśli, ale zawsze w jakiś sposób «wymianą darów»"27. Zdecydowanie przekracza więc granice konwersacji. Ma bowiem prowadzić do prawdziwie osobowego spotkania z Bogiem i między ludźmi ${ }^{28}$.

Benedykt XVI zdecydowanie opowiada się za dialogicznym rozumieniem teologii, wyrażającym się przede wszystkim w nieustannym dialogu wiary i rozumu, prowadzącym ku Temu, który jest zarówno Podmiotem, jak i Przedmiotem owego dialogu. Dialog między rozumem i wiarą prowadzony szczerze i konsekwentnie pozwala dostrzec racjonalność wiary w Boga. Chodzi tu nie o jakiegokolwiek Boga, ale o Boga objawiającego się w Jezusie Chrystusie, bo tylko w Nim spełniają się wszystkie prawdziwe pragnienia człowieka ${ }^{29}$. Wiara dopełnia rozum i go doskonali, a rozum, oświecony przez wiarę, znajduje moc, by wznieść się do poznania Boga i rzeczywistości duchowych. „Wiara i rozum nie tylko nie mogą nigdy pozostawać w niezgodzie, ale się wzajemnie wspomagają, gdyż prawy ro-

25 Zob. Z. Glaeser, Droga dialogu - droga pojednania, w: P. Jaskóła (red.), Pojednanie narodów i Kościołów. Materiały sympozjum poświęconego problematyce II Europejskiego Zgromadzenia Ekumenicznego - Graz'97, Opole 1997, s. 119-120.

26 Jan PaweŁ II, Encyklika Ut unum sint, Rzym 1995, 28.

27 Tamże.

28 Zob. Z. Glaeser, Ku eklezjologii „Kościołów siostrzanych”. Studium ekumeniczne, Opole 2000, s. 237-238.

29 Zob. Benedy XT XVI, Radość płynąca $z$ wiary $i$ wychowanie nowych pokoleń. Do uczestników kongresu diecezji Rzymu, OsRomPol, 12 (2006), s. 15. 
zum ukazuje podstawy wiary, a oświecony jej światłem oddaje się wiedzy w sprawach Bożych. Z kolei wiara uwalnia i chroni umysł przed błędami i naucza go różnorakiej wiedzy"30.

\section{Teologia jako próba wypowiedzenia Niewypowiadalnego}

Każda prawda domaga się jej wyrażenia, uzewnętrznienia. Wypowiedzi o Bogu i o relacji człowieka z Bogiem mogą mieć różny charakter i mogą przybierać różne kształty. Ostatecznie chodzi jednak o próbę wypowiedzenia tego, co ze swej istoty jest niewypowiadalne, a jednak $\mathrm{w}$ jakiejś formie powinno zostać wypowiedziane ${ }^{31}$.

Najistotniejszym nośnikiem i znakiem prawdy teologalnej jest słowo. Ale i ono ma różną ekspresję i może być wyrażane na wiele sposobów. Bywa wprost wypowiadane w formie tez, twierdzeń, analiz i uzasadnień, ale może także przybrać charakter kontemplatywny. Znajduje wówczas zgoła inne formy wyrazu. Najczęściej jest to milczące zadumanie, prowadzące do spotkania z Chrystusem w wierze ${ }^{32}$. Tomasz Halík przestrzega przed mówieniem o Bogu ,z naiwnym poczuciem oczywistości jako o czymś przedmiotowo realnym”. Taką postawę określa jako "przejaw tupetu i bałwochwalstwa (...)"33. Stawia retoryczne pytanie: „Jak może w sposób autorytatywny mówić o życiu, o świecie, czy wreszcie o Bogu, ktoś, kto nie wypił do dna nawet kielicha własnego życia? (...) Bóg jest tym, który w szokujący sposób przerywa wywody ludzi zbyt pewnych swojej prawdy i prowadzi ich ku temu, co na koniec czyni Hiob: Już milczę, kładę sobie na ustach dłoń"34. Każda wypowiedź o Bogu

30 I Soвór WATYкAŃski, Konstytucja dogmatyczna o wierze katolickiej Dei Filius, 51, http://ptm.rel.pl/czytelnia/dokumenty/dokumenty-soborowe/sobor-watykanski-i/260konstytucja-dogmatyczna-o-wierze-katolickiej-dei-filius.html (odczyt z dn. 18.04.2019 r.).

31 Szerzej na ten temat zob. H. SŁAwıŃsKi, O możliwości i konieczności mówienia o Niewyrażalnym, „Studia Włocławskie” 19 (2017), s. 319-332.

32 Zob. KKK 2715.

33 T. HalíK, Wzywany czy niewzywany Bóg się tutaj zjawi. Europejskie wykłady z filozofii i socjologii dziejów chrześcijaństwa, tłum. A. Babuchowski, Kraków 2006, s. 290.

34 Tamże, s. 292; A. Świeżý́ski, Tajemnica i analogia we współczesnym mówieniu o Bogu, „Seminare” 1(35) (2014), s. 59. 
jest fragmentaryczna, cząstkowa. Zawiera w sobie element paradoksalności wynikającej z faktu niemożności jej wyrażenia w sposób całkowicie jednoznaczny i całościowy. Bóg Objawienia jest dynamiczny. Wciąż na nowo zaskakuje i zadziwia, ukazując się na granicy bytu i nicości, bliskości i oddalenia, poznania i niepojmowalności, wiary i zwątpienia. Nie można Go więc ani „zamknąç", ani „zmieścić”, ani też w pełni wypowiedzieć, stosując teologiczne formuły. Każda z nich naznaczona jest cząstkowością. Bóg wszakże pozostaje zawsze tajemnicą dla ludzkiego umysłu. Na tyle daje się poznać człowiekowi, na ile sam chce ${ }^{35}$.

Uwikłanie ludzkiego języka w określoną logikę, kontekst poznawczy, zawiłości semantyczne i osobiste doświadczenie życiowe stanowi poważne ograniczenie co do możliwości wypowiedzenia Tego, Którego $\mathrm{w}$ istocie nie można w pełni wypowiedzieć. Język teologii narażony jest na dwie skrajności. Jedną z nich jest twierdzenie, że o Bogu nie możemy nic powiedzieć, gdyż Boski Byt znajduje się całkowicie poza ludzką zdolnością mówienia o Nim. Druga ze skrajności wyraża się w przekonaniu, że terminy teologiczne mogą być używane jednoznacznie zarówno w mówieniu o Bogu, jak i o człowieku. Pewną próbą uniknięcia obu wskazanych skrajności jest zastosowanie w mówieniu o Bogu analogii ${ }^{36}$. Jest ona „sposobem używania słów, aby - w określonych okolicznościach - mogły powiedzieć coś o tym, kim jest Bóg i co czyni” ${ }^{37}$. „Broniąc zdolności ludzkiego rozumu do poznania Boga - czytamy w Katechizmie Kościoła katolickiego - Kościół wyraża swoją ufność w możliwość mówienia o Bogu wszystkim ludziom i z wszystkimi ludźmi"38. Autorzy Katechiz$m u$ dostrzegają jednak istotne ograniczenie co do możliwości orzekania o Bogu, wynikające z niedostatków ludzkiego poznania: „Ponieważ nasze poznanie Boga jest ograniczone, ograniczeniom podlega również nasz język, którym mówimy o Bogu. Nie możemy określać Boga inaczej, jak tylko biorąc za punkt wyjścia stworzenie, i to tylko według naszego

35 Zob. A. Świeżyński, Tajemnica $i$ analogia we współczesnym mówieniu o Bogu, dz. cyt., s. 60 .

36 Tamże.

37 J. Morales, Wprowadzenie do teologii, tłum. P. Rak, Kraków 2006, s. 132.

38 KKK 39. 
ludzkiego, ograniczonego sposobu poznania i myślenia"39. W ostatnim stwierdzeniu zawiera się przekonanie, że każda wypowiedź na temat Boga jest pochodną konkretnego doświadczenia Jego działania w świecie. Zatem, treść przekazu teologicznego, rozumianego jako Objawienie, jest zapośredniczona z języka wywodzącego się z prób opisania doświadczenia życiowego, które zostało zinterpretowane $\mathrm{w}$ kategoriach religijnych przez uczestniczące w nim osoby. Teologia, w swoim mówieniu o Bogu, odwołuje się do Objawienia, które jednak domaga się postawy szczególnego rodzaju otwartości, jaką jest wiara religijna. Argumentacja „z Objawienia" wyznacza także specyfikę nauk teologicznych. Przyjęcie faktu Objawienia oznacza, że Bóg w jakiś sposób przemawia do człowieka oraz że przekaz ten może być uchwycony i prawidłowo odczytany przez adresata. Jednocześnie stanowi to mocny argument teologiczny na rzecz tezy, że ludzki język, mimo wszelkich ograniczeń, nie jest całkiem bezradny w mówieniu o Bogu ${ }^{40}$.

W trakcie swojego wykładu wygłoszonego w Ratyzbonie papież Benedykt XVI podkreślił, że „nowożytny rozum naukowy, typowy dla nauk przyrodniczych (...) nosi w sobie (...) pytanie, które przerasta jego samego i jego możliwości metodologiczne. On sam musi (...) przyjąć, że materia ma strukturę racjonalną (...). Ale pytanie o przyczyny tego faktu istnieje i nauki przyrodnicze muszą je powierzyć filozofii i teologii, a więc refleksji prowadzonej na innych płaszczyznach i innymi sposobami”"41. Papież przekonuje więc, że „teologia nie da się zepchnąć ani do laboratorium, ani do zakrystii, lecz mówi człowiekowi to, czego nie powie mu żadna inna nauka: prawdę o własnej (człowieka) podstawie, czyli o istocie jego bytu. (...) Właśnie dlatego teologia (...) mierzy się w każdym czasie z największymi pytaniami człowieka i nauki"42. Teologia zajmuje się więc nie tylko Bogiem - jak wskazuje na to jej etymologiczna

\section{${ }^{39}$ KKK 40.}

40 Por. A. Świeżyński, Tajemnica $i$ analogia we współczesnym mówieniu o Bogu, dz. cyt., s. 61 .

41 Benedykt XVI, Wiara, rozum i uniwersytet - wspomnienia i refleksje (Ratyzbona, 12.09.2006), https://opoka.org.pl/biblioteka/W/WP/benedykt_xvi/przemowienia/ bawaria_ratyzbona_12092006.html (odczyt z dn. 17.04.2019 r.).

42 J. Szymiк, Theologia Benedicta, t. 1, Katowice 2010, s. 31. 
definicja, ale i człowiekiem. Poszukując w każdym czasie, w świetle Bożego objawienia odpowiedzi na najważniejsze pytania człowieka, próbuje $\mathrm{w}$ istocie rzeczy przy pomocy słów i znaków wypowiedzieć $\mathrm{w}$ jakiś sposób Niewypowiadalnego, by nieustannie budować zbawczą relację między Nim i człowiekiem.

Teologiczne poznanie Boga ma charakter podwójny: pozytywny i negatywny. W obydwu przypadkach chodzi o zaangażowanie całego człowieka, o wznoszenie się ku Bogu ludzkiego umysłu i serca, o próbę zbliżenia się do Boga, a w konsekwencji o jakąśs próbę wypowiedzenia Niewypowiadalnego. Myśl ludzka staje się tym bardziej ścisła, jasna, przenikliwa i trzeźwa im więcej w niej ducha podziwu, uwielbienia i otwarcia na rzeczywistość niewidzialną.

\section{Teologia jako doksologia}

Zgoła inny od zachodniego sposób wypowiadania Niewypowiadalnego proponuje chrześcijański Wschód. Dystansuje się od artykułowania $\mathrm{i}$ interpretowania prawd chrześcijańskiej wiary $\mathrm{w}$ formie teologicznych traktatów. Abstrahuje także od tworzenia wielkich teologicznych systemów pojęciowych. Przejmując bizantyjskie wzorce myślenia, chrześcijański Wschód ukształtował typ duchowości o ukierunkowaniu mistycznym, liturgicznym i ikonograficznym. Na pierwszy plan wysuwa kontemplacje Tajemnicy, a nie czysto racjonalne podejście do niej. Wychodzi z założenia, że kontemplacja Tajemnicy, otwarcie się na Jej oświecenie prowadzi do Jej poznawania, bez konieczności jej definiowania. Dogmat wpisuje więc ściśle w kontekst liturgiczny i doksologiczny, jako uwielbienie Boga i Jego zwycięskiej Prawdy. Dogmat staje się wówczas integralną częścią liturgii, niejako słowną ikoną Prawdy ${ }^{43}$.

W Tradycji chrześcijańskiej pierwszego tysiąclecia rozumienie dogmatu bardzo mocno łączono z biblijnym pojęciem prawdy. Prawda w sensie biblijnym opiera się na tożsamości Bożych obietnic w stosunku do ich wy-

${ }^{43}$ Por. W. Hryniewicz, Hermeneutyka $w$ dialogu. Szkice teologiczno-ekumeniczne, t. 2, Opole 1998, s. 42. 
pełnienia. Zakłada wierność Boga wobec raz danej obietnicy. Wychodzono z założenia, że nie można jej adekwatnie wyrazić przy pomocy ludzkich sformułowań. Ma ona bowiem wymiar dynamiczny ${ }^{44}$. Oznacza to, iż dotyczy nie tylko teraźniejszości, ale wykracza daleko ku przyszłości, przekraczając ludzkie oczekiwania. Implikuje w sobie element Bożego zaskoczenia, nieoczekiwania, nowości i pewnej nadwyżki ${ }^{45}$. Ma więc w sobie coś z otwartości. Można więc ją określić w kategoriach „bycia w drodze”. Na tym polega jej charakter dynamiczny, eschatologiczny i pneumatologiczny. Tym, który prowadzi ku pełni prawdy, jest Duch Święty (por. J 16,13). On jest Pocieszycielem, Duchem Prawdy. Jest też Świadkiem Prawdy (por. J 15,26). Oznajmia rzeczy przyszłe (por. J 16,13). Tych zaś, którzy przyjmują Prawdę, pobudza do dawania świadectwa o Prawdzie (por. J 15,26-27). Prawda zawarta $\mathrm{w}$ nowotestamentalnych wyznaniach wiary jest definitywna, gdyż w Jezusie Chrystusie Bóg objawił się ludzkości w sposób nieodwołalny (por. 2 Kor 1,20; Hbr 1,1). Zachowuje ona równocześnie charakter tymczasowy i fragmentaryczny (por. 1 Kor 13,9.12), w pełni zaś zostanie poznana dopiero w rzeczywistości eschatycznej ${ }^{46}$.

Biblijna koncepcja prawdy wycisnęla swe bogate piętno na wczesnochrześcijańskim rozumieniu dogmatu. Łączono więc nierozerwalnie dogmat z żywą wiarą Kościoła. Formuły wiary pojmowano przede wszystkim w sensie doksologicznym. Stanowily one integralną część liturgicznych obrzędów. Ich pierwszorzędnym celem nie była proklamacja jakiejś obiektywnej prawdy, ale wspólne wyznanie wiary. Dogmat pojmowano więc bardziej jako akt adoracji i dziękczynienia za dzieła, których Bóg dokonał dla człowieka i świata, a nie jako formułę o charakterze doktrynalnym. Taki też charakter posiadają orzeczenia pierwszych soborów. Zespalają one ze sobą elementy doktryny i modlitwy ${ }^{47}$. Dlatego znalazły swoje głębokie odzwierciedlenie liturgiczne.

${ }^{44}$ Zob. Z. Glaeser, Ku eklezjologii „Kościołów siostrzanych”, dz. cyt., s. 282-285.

45 Por. W. Kasper, Dogma unter dem Wort Gottes, Mainz 1965, s. 80-81.

46 Zob. W. Hryniewicz, Hermeneutyka $w$ dialogu, dz. cyt., s. 78.

47 Zob. DS 125-126; 150. Szczególnie żywa świadomość doksologicznego wymiaru dogmatu cechuje teologię prawosławną. Zachowała ona do dzisiaj pierwotne rozumienie dogmatu, nacechowane jednością doktryny, wyznania i liturgii. 
Z czasem dopiero dogmatowi nadano kontekst apologetyczny, wychodząc z założenia, że jest on poniekąd linią obronną wiary ${ }^{48}$. Ujęcie takie wydaje się być zbyt wąskie i nieodpowiadające szerokości sformułowań wiary w Kościele pierwotnym, których nie da się zrozumieć w świetle wąskiego pojęcia dogmatu ukształtowanego zwłaszcza w teologii potrydenckiej. Patrząc na dogmat z perspektywy pierwszego tysiąclecia, a więc jako na wspólne dziedzictwo Kościołów, kształtujące ich wiarę i życie liturgiczne, podkreślić należy, że nie chodzi tu jedynie o historyczną formę interpretacji wiary w Kościele, ale także o ustawiczną inspirację do dalszej interpretacji. Taką właśnie otwartą i dynamiczną koncepcję dogmatu proponuje były przewodniczący Papieskiej Rady dla Popierania Jedności Chrześcijan kard. Walter Kasper: „Dogmat jest owocem historycznego słuchania Pisma św.; przedstawia on zbieżny punkt różnych świadectw Pisma, tworzy horyzont, pod którym Pismo św. powinno być czytane i zapytywane. Jest to jednak horyzont, który posuwa się naprzód w procesie zrozumienia, jest otwarty, może poszerzać się, zachowując swoją tożsamość" ${ }^{49}$.

W świetle dynamicznej koncepcji prawdy i dogmatu cechującej wczesną Tradycję Kościoła, można właściwie zrozumieć potrzebę i sensowność ustawicznej reinterpretacji prawd wiary. Dogmat jest wynikiem historycznego doświadczenia Kościoła opartego na prawdzie ewangelicznej. Pomaga w orientowaniu aktu wiary we właściwym kierunku i w tym znaczeniu jest wyrazem definitywnej prawdy, chociaż z drugiej strony zachowuje charakter prowizoryczny i otwiera na przyszłość ${ }^{50}$. Każdy dogmat jest jedynie odzwierciedleniem niektórych aspektów prawdy objawionej. Musi więc pozostać otwarty, gdyż nie sposób za pomocą formuł wyrazić adekwatnie wiary Kościoła w osobową rzeczywistość Boga oraz prawdy objawione.

Również w dokumencie Kongregacji Nauki Wiary Mysterium Ecclesiae zaznacza się, że „znaczenie zawarte w wypowiedziach dotyczących wiary, częściowo zależy od specyfiki wyrażeniowej języka stosowanego w określo-

${ }^{48}$ Zob. P. Schoonenberg, Geschichtlichkeit und Interpretation des Dogmas, w: TENŻE, Die Interpretation des Dogmas, Düsseldorf 1969, s. 62-63.

49 W. Kasper, Dogma unter dem Wort Gottes, dz. cyt., s. 125. Zob. W. HryniewiCz, Hermeneutyka $w$ dialogu, dz. cyt., s. 82.

50 Zob. W. Hryniewicz, Hermeneutyka w dialogu, dz. cyt., s. 82. 
nym czasie i w określonych okolicznościach. Zdarza się także czasami, że jakaś prawda dogmatyczna zostaje najpierw wyrażona w sposób niepełny, chociaż nigdy nie błędny, a dopiero później, po rozważeniu jej w szerszym kontekście wiary i poznania ludzkiego, otrzymuje pełniejsze i doskonalsze wyrażenie. W nowych, kolejnych wypowiedziach Kościół zamierza potwierdzić lub pogłębić to, co w jakiś sposób jest już zawarte w Piśmie Świętym lub we wcześniejszych wypowiedziach Tradycji, chociaż równocześnie troszczy się o rozwiązanie pewnych problemów lub wyeliminowanie błędów. Wszystko to powinno być uwzględnione, by wypowiedzi Kościoła zostały prawidłowo wyjaśnione. W końcu należy dodać, że chociaż prawdy, których Kościół pragnie rzeczywiście nauczać w swoich formułach dogmatycznych, różnią się w zależności od zmiennych sposobów myślenia w różnych epokach i nie mogą być bez nich wyrażone, może zdarzyć się jednak niekiedy, że te same prawdy zostaną wyrażone przez Urząd Nauczycielski Kościoła przy pomocy pojęć, które odzwierciedlają wspomniane sposoby myślenia" ${ }^{1}$. Przedstawione stanowisko Kongregacji wobec sformułowań o charakterze dogmatycznym podkreśla potrzebę zachowania otwartości tychże sformułowań i ich doksologicznego osadzenia.

\section{Kontemplacja drogą do poznania Boga $\mathrm{i}$, ,językiem" teologii}

Święty Grzegorz z Nyssy przestrzegał przed niebezpieczeństwem ograniczania, czy wręcz „zamykania” Boga w formę definicji i pojęć, które okazują się jedynie „idolem Boga” ${ }^{52}$. Jest to przestroga przed „bałwochwalstwem pojęć", które nie prowadzą do poznania Boga, lecz raczej do fałszywych Jego wyobrażeń. Droga prawdziwego poznania weryfikuje się ustawicznie w akcie doksologii i zdumienia, który pozwala człowiekowi

${ }^{51}$ Kongregacja Nauki Wiary, Deklaracja o katolickiej doktrynie w Kościele przeciw niektórym współczesnym błędom Mysterium Ecclesiae, w: Z. Zimowski, J. Królikowski (tłum. i opr.), W trosce o petnię wiary. Dokumenty Kongregacji Nauki Wiary 1966-1994, Tarnów 1995, s. 59-60.

52 Zob. Grzegorz z Nyssy, De vita Moysis, II, 165, SCh., 1ter, 212. 
przeczuć coś z tajemnicy Boga bardziej niż samo rozumowanie ${ }^{53}$. Wyzwala od poczucia bałwochwalczej samowystarczalności pojęć i definicji ${ }^{54}$.

Podejmując intuicję św. Grzegorza z Nyssy, Wacław Hryniewicz mówi o „doksologii umysłu”. Chodzi mu o podkreślenie medytatywnego charakteru teologii, mającej swoje zakorzenienie i potwierdzenie w przeżyciu liturgicznym. Za ojcami wschodnimi zauważa, że właściwym organem percepcji duchowej jest tu „serce" rozumiane w sensie biblijnym i hezychastycznym ${ }^{55}$ jako duchowy ośrodek poznania integralnego i mądrościowego ${ }^{56}$. Tradycja bizantyjsko-słowiańska nazywa je często sercem inteligentnym, nie przeciwstawnym w stosunku do myśli, lecz pełniącym rolę scalającą i przeobrażającą. W nim dokonuje się niejako spotkanie Boga i człowieka. $Z$ doświadczenia tego tajemniczego „stykania się światów" rodzi się teologia w jej wymiarze osobowym i eklezjalnym. Z istoty swej ma ona w sobie pewien wymiar metapojęciowy, metalogiczny, misteryjny i niewyrażalny ${ }^{57}$.

Zaprezentowane myślenie zakorzenione jest $\mathrm{w}$ antropologii biblijnej: serce jest nie tylko siedliskiem uczuć, ale przede wszystkim ośrodkiem poznania, inteligencji, myśli, potrzeby sensu i wolności. „Światłe oczy serca" (Ef 1,18) - jak pisze św. Paweł - czynią zeń właściwy organ poznania Boga. Serce jest miejscem zmagania duchowego oraz decyzji za Bogiem lub przeciw Niemu. W tajemniczej głębi serca dokonuje się proces integracji lub rozpadu człowieczeństwa. W nim skupia się cały człowiek i przekracza sam siebie ${ }^{58}$.

53 Zob. TENŻE, In Canticum Canticorum, PG 44, 928.

${ }_{4}$ Zob. W. Hryniewicz, Hermeneutyka $w$ dialogu, dz. cyt., s. 42.

${ }_{55}$ Hezychazm to nurt duchowości, który rozwijał się wśród mnichów synajskich od czasów Jana Klimaka, a następnie w klasztorach na górze Athos. Podkreśla on rolę nieustannej modlitwy wewnętrznej, wiodącej do stanu wyciszenia i umożliwiającej przyjęcie daru Bożego światła, utożsamianego z jasnością góry Tabor, zob. Filokalia. Teksty o modlitwie serca, tłum. i opr. J. Naumowicz, Kraków 1998 (dalej: Filokalia), s. 324. Zob. także: J. Tofıluk, Hezychazm i jego wpływ na rozwój duchowości, http://psd.edu.pl/wp-content/uploads/2017/07/Hezychazm_i_jego_wplyw_na_rozwoj_duchowosci.pdf (odczyt $\mathrm{z}$ dn. 12.04.2019 r.).

56 Zob. W. Hryniewicz, Hermeneutyka $w$ dialogu, dz. cyt., s. 42.

57 Por. tamże.

58 Por. tamże, s. 43. 
Duchowa kontemplacja rzeczywistości widzialnej prowadzi do odkrycia jej sakramentalnego charakteru. Świat jawi się wówczas jak wielki znak Bożej obecności urzeczywistnionej najpełniej w człowieczeństwie Logosu - Boga wcielonego. Tak rozumiany świat nie jest rzeczywistością zamkniętą, lecz otwartą, przejrzystą i sakramentalną, mogącą prowadzić serce inteligentne do odkrywania i poznania „Niepoznawalnego”. Przemawia. Prowadzi ku Niewypowiadalnemu, który zawsze pozostaje „Bogiem ukrytym” (Iz 45,15). Odkrywa Jego tajemnicę, równocześnie ją zakrywając.

$\mathrm{Na}$ istotną rolę serca w ludzkim poznaniu szczególną uwagę zwracał bizantyjski hezychazm. Głosił, że „poznanie integralne dokonuje się przez zespolenie inteligencji i serca; że przybiera postać przejrzystej, czystej integralności zgodnej z mądrością (...), co nadaje mu charakter sapiencjalny, mądrościowy, nie dający się niczym innym zastąpić. «Zstąpienie» umysłu do serca ma dobroczynny wpływ dla obydwu. Jest ocaleniem zarówno dla inteligencji, jak i dla serca. Trzeba wówczas mówić o nich jak o jednej duchowej zdolności «umysło-serca». Umysł kontemplatywny i mądrościowy obdarzony jest «wyczuciem Boga», Jego piękna i tajemnicy w stworzeniach. Zrozumienie pochodzące od «serca duchowego» ma charakter bezpośredni i całościowy, ogarniający intuicyjnie rzeczywistość duchową. Nie jest to poznanie typu czysto racjonalnego, wyrozumowane i linearne, lecz «filozofia serca»" ${ }^{9}$. Opiera się na kontemplacji Bożej prawdy. Ma więc charakter epikletyczny i doksologiczny. Jej szczególnym wyrazem jest „Modlitwa Jezusowa”. Jej początki sięgają VI stulecia. Zasadniczo rozwinęła się w średniowieczu i jest żywo pielegnowana także w naszych czasach, zwłaszcza w klasztorach, a także pośród wiernych ${ }^{60}$. Można ją nazwać „sercem prawosławia” ${ }^{61}$. Jej tradycja sięga czasów biblijnych. Już słowa Boga skierowane do Abrahama

\section{Tamże.}

${ }^{60}$ Zob. E. Walewander, „Modlitwa Jezusa” w Kościele Wschodnim, w: W. Słomka (red.), Kontemplacja i działanie, Lublin 1984, s. 214-215.

61 Zob. Mnich Kościoła Wschodniego, Modlitwa Jezusowa, Kraków 1993, s. 6. Zob. też S. Andronowska, Modlitwa Jezusowa, „Wiadomości Polskiego Autokefalicznego Kościoła Prawosławnego" 4 (1975), s. 4. 
„Służ mi i bądź nieskazitelny” (Rdz 17,1) wzywają do nieustannej modlitwy. Również Nowy Testament zawiera szereg tekstów, które wzywają do ciągłej modlitwy. Jezus przykazał swoim uczniom, „że zawsze powinni się modlić i nie ustawać" (Łk 18,1, zob. Łk 18,1-8). Wyraźne początki „Modlitwy Jezusowej” wiążą się z ojcami pustyni. Pustelnicy i mnisi Kościoła pierwszych wieków widzieli w ciągłej modlitwie najskuteczniejszy środek do poznania Boga i wypełnienia przykazania: „Będziesz miłował Pana, Boga swego, całym swoim sercem, całą swoją duszą, całym swoim umysłem i całą swoją mocą" (Mk 12,30). Dążenie do ciągłego myślenia o Bogu miało na celu osiągnięcie żywej i osobowej wspólnoty z Nim.

„Modlitwa Jezusowa” jest wzywaniem Jezusa miłosiernego przy równoczesnym wyznaniu własnej grzeszności. Nieustanne wzywanie Imienia Jezus powoduje, że człowiek zaczyna wnikać w misterium Boga ${ }^{62}$. „Modlitwa Jezusowa” zawiera w sobie „całą naukę Ewangelii”, jest „Ewangelią w skrócie". W tak krótkiej formule modlitewnej zawarta jest nauka o dwóch naturach w Chrystusie, o Jego wcieleniu oraz o Trójcy Świętej. W pierwszej części formuły - poprzez adorację Imienia Jezus - podkreślana jest ludzka natura Jezusa Chrystusa, a następnie wzywana jest Jego Boska natura - nazywa się Go Panem i Synem Bożym. Pierwsza część modlitwy jest również doksologią Trójcy Świętej. Pomimo tego, że skierowana jest do Jezusa Chrystusa, wskazuje również na Boga Ojca - Chrystus, bowiem nazwany jest Synem Bożym - oraz na Ducha Świętego, gdyż „Nikt też nie może powiedzieć bez pomocy Ducha Świętego «Panem jest Jezus»” (1 Kor 12,3). W ten sposób w „Modlitwie Jezusowej” kryją się zasadnicze prawdy chrześcijańskiej wiary ${ }^{63}$. To ona oczyszcza ludzką duszę i przysposabia człowieka do przyjęcia Boga. Oświeca, ożywia, przezwycięża wrogów widzialnych i niewidzialnych, by w końcu doprowadzić do mistycznego poznania Boga.

Celem „Modlitwy Jezusowej” jest doprowadzenie do działania w człowieku Ducha Świętego oraz do połączenia życia ludzkiego z życiem

${ }^{62}$ Zob. P. P. OGóRek, Mistyka chrześsijańskiego Wschodu i Zachodu, Warszawa 2002, s. 253-254.

${ }^{63}$ Zob. S. Hrycuniak, Modlitwa Jezusowa, w: K. Leśniewski, J. Leśniewska (red.), Prawosławie. Światło wiary i zdrój doświadczenia, Lublin 1999, s. 148. 
Jezusa Chrystusa. Cel „Modlitwy Jezusowej” to również przebóstwienie człowieka. Siergiej Bułgakow pisze: „Imię Jezusa, obecne w sercu ludzkim, nadaje mu moc przebóstwienia"64.

„Modlitwa Jezusowa” skupia ludzki umysł na dwóch najważniejszych kwestiach, niezbędnych do tego, by wejść we właściwe relacje z Bogiem: stałej obecności Bożej i poczuciu własnej grzeszności. Częste i ciągłe powtarzanie modlitwy wprowadza człowieka, jego umysł i serce, w sferę przebóstwiającej mocy Ducha Świętego. Oznacza to pełne zespolenie człowieka z Bogiem. Światło Bożego Ducha przenika ludzkie życie. Wprowadza w nie nowy impuls. Nie neguje świata, lecz przemienia go, nie odrzuca stworzenia Bożego, lecz odbiera i ocenia według nowych kryteriów, jako istotę pochodzącą od Boga. Staje się szczególną drogą poznania Boga i zjednoczenia z Nim.

\section{Apofatyczna droga teologicznego poznania Boga}

Kiedy ludzki umysł zespolony z sercem dochodzi do przeczucia niewystarczalności katafatycznej drogi poznania Boga, kieruje się wówczas ku apofatyzmowi ${ }^{65}$. U podstaw takiego stanu rzeczy leży przekonanie, że wszelkie analogie, obrazy i pojęcia zaczerpnięte ze świata stworzonego nie są w stanie adekwatnie wyrazić tajemnicy Boga. Poczucie nieadekwatności i ograniczoności pozytywnych cech przypisywanych Bogu skłania umysł i serce do wzniesienia się ponad wszelkie pojęcia pozytywne. Nie oznacza to ich całkowitego odrzucenia. Bóg jest taki, jakim Go przeczuwa w stworzeniu ludzki umysł, a zarazem jest Inny, absolutnie transcendentny w stosunku do rzeczywistości świata stworzonego ${ }^{66}$.

Teologia apofatyczna jest próbą teologicznego odkrywania Niepoznawalnego i wyrażania Niewyrażalnego charakterystyczną przede wszystkim dla chrześcijaństwa wschodniego. Posługuje się metodą negacji, antynomii, paradoksu, doświadczenia mistycznego i kontemplacji w poznaniu

64 Za: tamże, s. 157-159.

65 Zob. W. Hryniewicz, Apofatyczna teologia, w: F. Gryglewicz, R. Łukaszyk, Z. Sułowski (red.), Encyklopedia katolicka, t. 1, Lublin 1995, kol. 745-748.

66 Por. W. Hryniewicz, Hermeneutyka $w$ dialogu, dz. cyt., s. 49-50. 
Boga i tajemnic wiary. Jest nie tyle intelektualnym poszukiwaniem pozytywnego poznania Boga, ile raczej mistycznym doświadczeniem, oczyszczeniem i drogą do przemiany. U podstaw tego typu myślenia leży przekonanie, że Bóg przewyższa wszelkie możliwości zrozumienia Go. Może być poznany jedynie przez nie-poznanie. Apofatyczna droga ku Niepoznawalnemu unika formułowania prawd wiary przy użyciu terminów czysto racjonalnych, zaczerpniętych z filozofii. Jest wyrazem postawy umysłu i serca, dążących do kontemplacji prawd objawionych, wyrażającej szacunek człowieka wobec niepoznawalności Boga. Podstawową zasadę teologii apofatycznej można wyrazić twierdzeniem, że o Bogu wiemy, iż jest, nie wiemy jednak, Kim On jest. Grzegorz z Nazjanzu uważa, że „wypowiedzenie Boga jest rzeczą niemożliwą, a pojęcie Go rozumem jest jeszcze bardziej niemożliwe" ${ }^{17}$.

Akcentując w sposób radykalny niepoznawalny charakter Boga, apofatyzm wyraża prawdę nie tyle o naturalnej niezdolności poznawczej człowieka, ile raczej o transcendentnej głębi istoty Bożej. Bóg jest misterium niepoznawalnym z racji swej natury. Można Go jedynie poznać przez niewiedzę, przy pomocy języka negatywnego, wyrażającego to, czym Bóg nie jest ${ }^{68}$.

Apofatyczna droga usiłuje doprowadzić do poznania mistycznego, o charakterze paradoksalnym, które dociera w sposób intuicyjny do Tego, który jest ze swej istoty Niepojęty. Myślenie apofatyczne uzdalnia wierzącego do wzniesienia się ponad pojęcia i rozumowe spekulacje. Prowadzi do pozytywnego przeświadczenia o istnieniu transcendentnej i niewyrażalnej rzeczywistości, wykraczającej poza wszelkie twierdzenia pozytywne. Wybiera raczej metodę antynomii i paradoksu jako sobie właściwą, wychodząc z założenia, że Bóg przewyższa wszystkie pojęcia i wszelkie dyskursywne rozumowanie. Przyjmuje metodę równoczesnej afirmacji i negacji: Bóg „jest”, a zarazem „nie jest”. Obydwa twierdzenia są w równej mierze prawdziwe i nieprawdziwe, gdyż Bóg przewyższa wszelki byt

${ }^{67}$ Grzegorz z Nazjanzu, Mowy, 28, 4, w: Mowy wybrane, tłum. T. Sinko, J. Sajdak, S. Kazikowski, Warszawa 1967, s. 287.

${ }^{68}$ Zob. P. Evdokimov, Prawosławie, tłum. J. Klinger, Warszawa 1986, s. 223. 
jak i nie-byt. Jest ponad wszelką istotą. Teologia apofatyczna uświadamia, że Bóg przewyższa ludzkie zdolności poznawcze i że droga do Niego jest drogą poznania ponadpojęciowego, intuicyjnego i mistycznego ${ }^{69}$. Ceni więc niezwykle doświadczenie duchowe, prowadzące do spotkania z Bogiem przez niewiedzę i ciemność. Jej celem nie jest tworzenie abstrakcyjnego systemu pojęciowego, ale pomoc ludzkiemu umysłowi w dochodzeniu do kontemplacji tajemnic Bożych. Ostatecznie apofatyczna droga prowadzi człowieka do wewnętrznego przeobrażenia i do zjednoczenia z Bogiem. Jest pełnym czci świadectwem składanym Duchowi Świętemu, który w swej osobowej intymności pozostaje nadal nieznany, jakkolwiek uzdalnia ludzki umysł do wznoszenia się ponad własne ograniczenia. Ma więc charakter epikletyczny i doksologiczny, a w ostateczności mistyczny. Charakteryzuje ją milczenie przyjmujące kształt pełnego nadziei oczekiwania zakotwiczonego w wierze. Oczekiwanie to tradycja wschodnia określa jako stan czystej modlitwy i epiklezy, gdzie na plan dalszy odsuwa się wszelką myśl i wszelkie pojęcie, choćby najbardziej pozytywne. Zawiesza się wyobraźnię i chęć widzenia prawdy. Jest to milczenie intelektu ukrzyżowanego, ogołoconego i opróżnionego - stan ofiarowania sięgający w najgłębsze tajniki ,serca inteligentnego", będącego duchowym ośrodkiem całej osoby ludzkiej. W ten sposób dokonuje się oczyszczenie i przeobrażenie intelektu na drodze ku doksologii ${ }^{70}$.

Apofatyzm to jedna z dróg komplementarnie prowadzących ku Niewypowiadalnemu. Otwiera dla teologii pozytywnej horyzonty kontemplatywnego doświadczenia tajemnicy Boga. Pozwala Go w jakiś sposób wypowiedzieć własnym przeżyciem, które najczęściej wyraża się szeroko pojętym milczeniem o charakterze epikletycznym i doksologicznym.

${ }^{69}$ Zob. T. DzIDEK, Granice rozumu w teologicznym poznaniu Boga, Kraków 2001, s. 311-316.

70 Por. W. Hryniewicz, Hermeneutyka $w$ dialogu, dz. cyt., s. 55. 


\section{Ku teologii uprawianej na klęcząco}

Papież Franciszek w czasie spotkania z pracownikami naukowymi Papieskiego Uniwersytetu Gregoriańskiego oraz instytutów stowarzyszonych wygłosił przemówienie pod znamiennym tytułem: Teolodzy na klęczkach i z umysłem otwartym (Rzym, 10.04.2014 r.). Poruszył w nim m.in. kwestię relacji między teologicznym studium a życiem duchowym, zachęcając teologów do ciągłego pogłębiania ich duchowego życia i do uprawiania teologii na kolanach: „Wasz wysiłek intelektualny w nauczaniu i w badaniach, w studiowaniu i w szerszej formacji będzie tym bardziej owocny i skuteczny, gdy będzie ożywiany przez miłość do Chrystusa i do Kościoła, im silniejsza i bardziej harmonijna będzie więź między studiami a modlitwą. To nie jest sprawa starodawna, to jest istota! Jest to jedno z wyzwań naszych czasów: przekazywać wiedzę i dostarczać klucz do jej życiowego rozumienia, a nie zbiór pojęć ze sobą niepowiązanych. Potrzebna jest prawdziwa hermeneutyka ewangeliczna, aby lepiej zrozumieć życie, świat, ludzi, nie synteza, ale duchowy klimat badań i pewności opartej na prawdach rozumu i wiary. Filozofia i teologia pozwalają nabyć przekonań, które kształtują i umacniają intelekt oraz oświecają wolę, ale to wszystko jest owocne jedynie wtedy, gdy czyni się to z umysłem otwartym i na klęczkach. Teolog, który zadowala się swoją myślą, pełną i zamkniętą, jest przeciętny. Dobry teolog i filozof ma umysł otwarty, czyli niekompletny, zawsze otwarty na maius Boga i prawdy, zawsze rozwijający się, zgodnie z ową zasadą, którą św. Wincenty z Lerynu opisuje w następujący sposób: «annis consolidetur, dilatetur tempore, sublimetur aetate» (Commonitorium primum, 23, PL 50, 668): ugruntowuje się z latami, poszerza się z czasem, pogłębia się z wiekiem. Taki jest teolog, mający otwarty umysł. Natomiast teolog, który się nie modli i nie wielbi Boga, popada ostatecznie w najbardziej odrażający narcyzm. A to jest choroba kościelna. Wiele zła wyrządza narcyzm teologów, myślicieli, jest odrażający"71.

71 FranciszeK, Teolodzy na klęczkach i z umysłem otwartym (przemówienie do pracowników Papieskiego Uniwersytetu Gregoriańskiego oraz instytutów stowarzyszonych, Rzym, 10.04.2014 r.), https://opoka.org.pl/biblioteka/W/WP/franciszek_i/przemowienia/ gregorianum_10042014.html (odczyt z dn. 14.04.2019 r.). 
W przemówieniu skierowanym do uczestników Międzynarodowego Kongresu Teologicznego w Buenos Aires Franciszek podkreślił, że teologię należy uprawiać na kolanach przed ołtarzem refleksji oraz „,z radością i nadzieją". Stwierdził, że jako człowiek wierzący „teolog jest kimś, kto doświadczył Jezusa Chrystusa i odkrył, że bez Niego nie może już żyć". Wyjaśnił, że teolog wie, iż Bóg uobecnia się jako słowo, milczenie, rana, uzdrowienie, jako śmierć i zmartwychwstanie. Teolog to ten, kto wie, że jego życie jest naznaczone tym śladem i znakiem, który pozostaje otwarty na głód, niepokój, ciekawość i życie, kto wie, że nie może żyć bez przedmiotu/podmiotu swej miłości i poświęca swe życie, aby móc dzielić je ze swymi braćmi ${ }^{72}$.

„Teologia jest świętością myśli i modlącym się blaskiem, przede wszystkim zaś pokorą, która pozwala nam ułożyć nasze serce i nasze myśli zgodnie z «Bogiem, który zawsze jest największy»" - powiedział na zakończenie swego orędzia Franciszek. I dodał: „Nie bójmy się uklęknąć przed ołtarzem refleksji i czynić to «z radością i nadzieją, smutkiem i lękiem ludzi naszych czasów»"73.

Do uprawiania teologii na klęcząco wielokrotnie zachęcał także Benedykt XVI. Wyraźnie o tym mówił w czasie przemówienia wygłoszonego 10 września 2007 roku w Akademii Teologicznej w austriackim Heiligenkreuz. Uczynił to pod wpływem inspiracji medytacji Hansa Ursa von Balthasara. Według Benedykta XVI ten właśnie styl może oznaczać szansę na powrót w uprawianiu teologii do prymatu Boga i świata Bożego w rzeczywistości doczesnej, do odkrycia zdrowej duchowości eklezjalnej oraz większego zaufania do wiary i do Objawienia, jak również zdynamizowania nowego, radosnego i głębokiego duszpasterskiego zaangażowania Kościoła ${ }^{74}$.

${ }^{72}$ G. GaŁĄzKa, Papież do teologów w Argentynie: teologię trzeba uprawiać na kolanach przed ołtarzem refleksji, http://www.niedziela.pl/artykul/17766/Papiez-do-teologow-w-Argentynie-teologie (odczyt z dn. 17.04.2019 r.).

73 Tamże.

74 Zob. J. Tomaszewski, Teologia na kolanach, http://christianitas.org/news/teologia-na-kolanach/ (odczyt z dn. 10.04.2019 r.). 
Formą podsumowania powyższego opracowania niech będzie nawiązanie do Orędzia Benedykta XVI na Światowy Dzień Środków Społecznego Przekazu ${ }^{75}$ z 2012 roku. Papież wskazał wówczas na milczenie i słowo jako dwa równoważne wymiary komunikacji. Powinny one następować po sobie i się dopełniać. Mają przecież wspólny cel: doprowadzenie do autentycznego dialogu i do pogłębienia bliskości człowieka z Bogiem oraz ludzi między sobą.

W odniesieniu do międzyludzkiej komunikacji papież stwierdza: „W milczeniu słyszymy i poznajemy lepiej samych siebie, rodzi się i pogłębia myśl, z większą jasnością rozumiemy to, co chcemy powiedzieć, albo to, czego oczekujemy od drugiego, dokonujemy wyboru jak wyrazić siebie. Milknąc, pozwalamy drugiej osobie mówić, wyrazić siebie, a sobie samym na to, by nie być przywiązanymi jedynie do naszych słów czy też naszych idei, bez stosownej wymiany myśli. (...) W milczeniu przemawiają radość, zmartwienia, cierpienie, które właśnie w nim znajdują szczególnie intensywną formę wyrazu. Tak więc z milczenia wynika komunikacja jeszcze bardziej wymagająca, przywołująca wrażliwość i tę zdolność słuchania, która często ukazuje miarę i charakter więzi. Tam, gdzie jest dużo wiadomości i informacji, milczenie staje się niezbędne do rozróżnienia tego, co jest ważne, od tego, co jest zbędne lub drugorzędne"76.

W swoich rozważaniach idzie znacznie dalej. Podkreśla, że milczenie jest przestrzenią, w której rodzą się najistotniejsze pytania: Kim jestem? Co mogę wiedzieć? Co powinienem czynić? Na co mogę mieć nadzieję? I dodaje: Samotność i milczenie są uprzywilejowanymi przestrzeniami, które pomagają ludziom w odnalezieniu samych siebie i Prawdy, która nadaje sens wszystkim rzeczom. Bóg biblijnego Objawienia przemawia także bez słów: „Jak pokazuje krzyż Chrystusa, Bóg przemawia również milczeniem. Milczenie Boga, doświadczenie oddalenia Wszechmogącego i Ojca stanowi decydujący etap ziemskiej drogi Syna Bożego,

75 Benedy кт XVI, Orędzie Benedykta XVI na Światowy Dzień Środków Społecznego Przekazu (25.01.2012 r.), http://www.osservatoreromano.va/pl/news/miedzy-milczeniem-a-sowem (odczyt z dn. 16.03.2019 r.).

76 Tamże. 
wcielonego Słowa. (...) Milczenie Boga jest przedłużeniem Jego poprzednich słów. W tych mrocznych chwilach przemawia On w misterium swego milczenia"77. W milczeniu krzyża przemawia elokwencja miłości Boga, przeżywanej aż do największego daru. Po śmierci Chrystusa ziemia trwa w milczeniu i w Wielką Sobotę, kiedy „Król zasnął, a Bóg w ludzkim ciele wzbudził tych, którzy spali od wieków"78, rozbrzmiewa głos Boga pełen miłości dla rodzaju ludzkiego.

Jeżeli Bóg mówi do człowieka także w milczeniu, to i człowiek w milczeniu może prowadzić dialog z Bogiem i o Bogu. „Potrzebujemy milczenia - stwierdza Benedykt XVI - które staje się kontemplacją, pozwalającą nam wejść w milczenie Boga i w ten sposób dotrzeć tam, gdzie rodzi się Słowo, Słowo odkupieńcze"79. Mówiąc o wielkości Boga, nasz język okazuje się zawsze niekompletny, zawodny, mało odpowiedni. W ten sposób otwiera się przestrzeń milczącej kontemplacji. Z niej rodzi się pilna potrzeba misji, potrzeba "oznajmiania tego, cośmy ujrzeli i usłyszeli” (por. 1 J 1,3). Milcząca kontemplacja pozwala zanurzyć się w źródle Miłości, które prowadzi ku drugiemu człowiekowi, „by odczuć jego ból i dać mu światło Chrystusa, Jego orędzie życia, Jego dar całkowitej miłości, która zbawia" ${ }^{\prime 0}$. Benedykt XVI nawiązuje do stwierdzenia Konstytucji dogmatycznej o Objawieniu Bożym Dei verbum II Soboru Watykańskiego, podkreślając, że Boże Objawienie urzeczywistnia się „przez czyny i słowa wewnętrznie $\mathrm{z}$ sobą powiązane, tak że czyny dokonane przez Boga $\mathrm{w}$ historii zbawienia ilustrują i umacniają naukę oraz sprawy słowami wyrażone, słowa zaś obwieszczają czyny i odsłaniają tajemnicę w nich zawartą" ${ }^{11}$. Ten właśnie plan zbawienia ma swój szczyt w osobie Jezusa

77 Tenże, Adhortacja apostolska Verbum Domini, Rzym 2010.

78 Por. Oficjum czytań Wielkiej Soboty.

79 Benedykt XVI, Homilia podczas Mszy św. na zakończenie sesji plenarnej Międzynarodowej Komisji Teologicznej (06.10.2006 r.), http://w2.vatican.va/content/benedict-xvi/ pl/homilies/2006/documents/hf_ben-xvi_hom_20061006_commissione-teologica.html (odczyt z dn. 12.05.2019 r.).

80 Tenże, Orędzie Benedykta XVI na Światowy Dzień Środków Społecznego Przekazu, dz. cyt.

${ }^{81}$ II Sobór Watykański, Konstytucja dogmatyczna o Objawieniu Bożym Dei verbum, Rzym 1965, 2. 
z Nazaretu, Pośrednika i Pełni całego Objawienia. On objawił prawdziwe oblicze Boga, a przez swój krzyż i zmartwychwstanie przeprowadził człowieka $\mathrm{z}$ niewoli grzechu i śmierci do wolności dzieci Bożych. Również podstawowe pytanie dotyczące sensu ludzkiego życia znajduje odpowiedź w tajemnicy Chrystusa. Z niej rodzi się misja Kościoła. Ona pobudza chrześcijan do głoszenia nadziei i zbawienia oraz do dawania świadectwa miłości, która promuje ludzką godność i buduje sprawiedliwość i pokój. Owa przestrzeń milczącej kontemplacji jest szczególnym obszarem dla owocnego uprawiania teologii. To chyba jedno z ważnych zadań, jakie staje przed nami jako teologami: budować w teologicznych dociekaniach zdrową równowagę między słowem i kontemplatywnym milczeniem.

\section{Bibliografia}

Andronowska S., Modlitwa Jezusowa, „Wiadomości Polskiego Autokefalicznego Kościoła Prawosławnego" 4 (1975), s. 4-23.

Benedykt XVI, Adhortacja apostolska Verbum Domini, Rzym 2010.

Benedykt XVI, Dawajcie świadectwo o Bogu w świecie współczesnym. Rozmowa z młodzieżą Rzymu i Lacjum na placu św. Piotra, OsRomPol 6-7 (2006), s. 51 .

Benedykt XVI, Homilia podczas Mszy św. na zakończenie sesji plenarnej Międzynarodowej Komisji Teologicznej (06.10.2006 r.), http://w2.vatican. $\mathrm{va} /$ content/benedict-xvi/pl/homilies/2006/documents/hf_ben-xvi_ hom_20061006_commissione-teologica.html (odczyt z dn. 12.05.2019 r.).

Benedykt XVI, Orędzie Benedykta XVI na Światowy Dzień Środków Społecznego Przekazu (25.01.2012 r.), http://www.osservatoreromano.va/pl/news/miedzy-milczeniem-a-sowem (odczyt z dn. 16.03.2019 r.).

Benedykt XVI, Radość płynąca z wiary i wychowanie nowych pokoleń. Do uczestników kongresu diecezji Rzymu, OsRomPol, 12 (2006), s. 15.

Benedykt XVI, Wiara i rozum w nauczaniu św. Augustyna (audiencja generalna, 30.01.2008 r.), https://www.niedziela.pl/artykul/84572/nd/ (odczyt z dn. 15.02.2019 r.). 
Benedykt XVI, Wiara, rozum i uniwersytet - wspomnienia i refleksje (Ratyzbona, 12.09.2006 r.), https://opoka.org.pl/biblioteka/W/WP/benedykt_xvi/przemowienia/bawaria_ratyzbona_12092006.html (odczyt z dn. 17.04.2019 r.).

Dola T., Historyczny kształt prawdy, w: S. Rabiej (red.), Prawda wobec rozumu i wiary, Opole 1999, s. 97-106.

Dzidek T., Granice rozumu w teologicznym poznaniu Boga, Kraków 2001.

Evdokimov P., Prawosławie, tłum. J. Klinger, Warszawa 1986.

Filokalia. Teksty o modlitwie serca, tłum. i opr. J. Naumowicz, Kraków 1998.

Franciszek, Teolodzy na klęczkach i z umysłem otwartym (przemówienie do pracowników Papieskiego Uniwersytetu Gregoriańskiego oraz instytutów stowarzyszonych, Rzym, 10.04.2014 r.), https://opoka.org.pl/biblioteka/W/ WP/franciszek_i/przemowienia/gregorianum_10042014.html (odczyt $\mathrm{z}$ dn. 14.04.2019 r.).

Gałązka G., Papież do teologów w Argentynie: teologię trzeba uprawiać na kolanach przed ottarzem refleksji, http://www.niedziela.pl/artykul/17766/ Papiez-do-teologow-w-Argentynie-teologie (odczyt z dn. 17.04.2019 r.).

Glaeser Z., Droga dialogu - droga pojednania, w: P. Jaskóła (red.), Pojednanie narodów i Kościołów. Materiały sympozjum poświęconego problematyce II Europejskiego Zgromadzenia Ekumenicznego - Graz'97, Opole 1997, s. 117-126.

Glaeser Z., Ku eklezjologii „Kościołów siostrzanych”. Studium ekumeniczne, Opole 2000.

Grzegorz z Nazjanzu, Mowy, 28, 4, w: Mowy wybrane, tłum., T. Sinko, J. Sajdak, S. Kazikowski, Warszawa 1967, s. 287.

Grzegorz z Nyssy, De vita Moysis, II, 165, SCh., 1ter, 212.

Grzegorz z Nyssy, In Canticum Canticorum, PG 44, 928.

Halík T., Wzywany czy niewzywany Bóg się tutaj zjawi. Europejskie wykłady z filozofii i socjologii dziejów chrześcijaństwa, tłum. A. Babuchowski, Kraków 2006.

Hrycuniak S., Modlitwa Jezusowa, w: K. Leśniewski, J. Leśniewska (red.), Prawosławie. Światło wiary i zdrój doświadczenia, Lublin 1999, s. 143-159.

Hryniewicz W., Apofatyczna teologia, w: F. Gryglewicz, R. Łukaszyk, Z. Sułowski (red.), Encyklopedia katolicka, t. 1, Lublin 1995, kol. 745-748.

Hryniewicz W., Hermeneutyka $w$ dialogu. Szkice teologiczno-ekumeniczne, t. 2, Opole 1998. 
Jan Paweł II, Encyklika Fides et ratio, Rzym 1998.

Jan Paweł II, Encyklika Ut unum sint, Rzym 1995.

Jan Paweł II, Kościót jest solidarny z uniwersytetem. Do środowiska naukowego $w$ Bolonii (Bolonia, 18.04.1982 r.), w: Jan Pawet II, Nauczanie społeczne, t. 5, cz. 1, Warszawa 1986, s. 93-100.

Jan Paweł II, Prawda i wolność. Do środowiska akademickiego (Rzym, 26.03.1981 r.), w: Jan Paweł II, Nauczanie społeczne, t. 4, Warszawa 1984, s. 74-75.

Jan Paweł II, Przekroczyć próg nadziei, Lublin 1994.

Jan Paweł II, Przemówienie Ojca Świętego do przedstawicieli świata nauki (Lublin, 09.06.1987 r.), http://www.nauczaniejp2.pl/dokumenty/wyswietl/ id/677 (odczyt z dn. 12.03.2019 r.).

Kasper W., Dogma unter dem Wort Gottes, Mainz 1965.

Katechizm Kościoła katolickiego, Poznań 1994.

Kongregacja Nauki Wiary, Deklaracja o katolickiej doktrynie w Kościele przeciw niektórym współczesnym błędom Mysterium Ecclesiae, w: Z. Zimowski, J. Królikowski (tłum. i opr.), W trosce o petnię wiary. Dokumenty Kongregacji Nauki Wiary 1966-1994, Tarnów 1995, s. 54-64.

Kowalczyk S., Prawda jako wartość w nauczaniu Jana Pawła II, „Ateneum Kapłańskie" 1(129) (530) (1997), s. 55-65.

Mnich Kościoła Wschodniego, Modlitwa Jezusowa, Kraków 1993.

Morales J., Wprowadzenie do teologii, tłum. P. Rak, Kraków 2006.

Ochotny P., Fides et ratio. Dwa porządki poznania prawdy, „Warszawskie Studia Pastoralne UKSW" 3(32) (2016), s. 101-119.

Ogórek P. P., Mistyka chrześcijańskiego Wschodu i Zachodu, Warszawa 2002.

Paweł VI, Encyklika Ecclesiam suam, Rzym 1964.

Possenti V., Filozofia i wiara, Kraków 2004.

Proniewski A., Problematyka wiary w nauczaniu Benedykta XVI, „Rocznik Teologii Katolickiej” 10 (2011), s. 113-130.

Schoonenberg P., Die Interpretation des Dogmas, Düsseldorf 1969.

Sienkiewicz E., Zagadnienie prawdy w filozofii, „Poznańskie Studia Teologiczne" 20 (2006), s. 309-325. 
Sławiński H., O możliwości i konieczności mówienia o Niewyrażalnym, „Studia Włocławskie" 19 (2017), s. 319-332.

I Sobór Watykański, Konstytucja dogmatyczna o wierze katolickiej Dei Filius, http://ptm.rel.pl/czytelnia/dokumenty/dokumenty-soborowe/sobor-watykanski-i/260-konstytucja-dogmatyczna-o-wierze-katolickiej-dei-filius. html (odczyt z dn. 18.04.2019 r.).

II Sobór Watykański, Konstytucja dogmatyczna o Objawieniu Bożym Dei verbum, Rzym 1965.

Szymik J., Theologia Benedicta, t. 1, Katowice 2010.

Świeżyński A., Tajemnica i analogia we współczesnym mówieniu o Bogu, „Seminare" 1(35) (2014), s. 59-69.

Tofiluk J., Hezychazm i jego wpływ na rozwój duchowości, http://psd.edu.pl/wp-content/uploads/2017/07/Hezychazm_i_jego_wplyw_na_rozwoj_duchowosci.pdf (odczyt z dn. 12.04.2019 r.).

Tomaszewski J., Teologia na kolanach, http://christianitas.org/news/teologia-na-kolanach/ odczyt z dn. 10.04.2019 r.).

Walewander E., „Modlitwa Jezusa” w Kościele Wschodnim, w: W. Słomka (red.), Kontemplacja i działanie, Lublin 1984, s. 213-221.

Węcławski T., Sieć. Wyprawa pierwsza. Pytanie o Jezusa, Kraków 1997.

Ks. prof. dr hab. Zygfryd Glaeser - dyrektor Instytutu Ekumenizmu i Badań nad Integracją Wydziału Teologicznego Uniwersytetu Opolskiego; kierownik katedry Teologii Kościołów Wschodnich; członek krajowych i zagranicznych towarzystw naukowych, m.in.: Gesellschaft zum Studium des Christlichen Ostens (GSCO), St. Irenaeus Joint Orthodox-Catholic Working Group. Członek Komisji Ewaluacji Nauki, Komisji ds. Stosunków Polsko-Czeskich i Polsko-Słowackich PAN; uczestnik obrad Katolicko-Prawosławnej Komisji do Dialogu Teologicznego (Boltimore 2000); konsultor Rady Episkopatu Polski ds. Ekumenizmu; delegat Konferencji Episkopatu Polski w międzynarodowym projekcie „Pojednanie w Europie Środkowo-Wschodniej” (współprzewodniczący projektu); autor i redaktor książek oraz artykułów z zakresu teologii dogmatycznej i ekumenicznej oraz z zakresu tematyki historyczno-integracyjnej, publikowanych w różnych językach. 